\title{
International Benchmarking of South Africa's Infrastructure Performance
}

\author{
by \\ Željko Bogetić and Johannes W. Fedderke
}

\begin{abstract}
The paper provides a first systematic, comprehensive international benchmarking of South Africa's infrastructure performance. The analysis focuses on four major sectors-electricity, water and sanitation, information and communication technology, and transportation. The benchmarking is performed against the relevant group of comparator countries using a new World Bank international data base with objective and perception-based indicators of infrastructure performance from over 200 countries. Specifically, we seek to answer a number of relevant questions: How does South Africa compare on major indicators of infrastructure sector performance against the relevant country groups? What do outcome indicators tell us about the relative strengths and weaknesses of South Africa's infrastructure vis-à-vis various income and geographical comparator groups of countries? Where are the largest deviations - positive and negative - from the benchmarks and other comparators? And how does one interpret some of these comparisons to be useful for policy purposes? The results suggest the following. Despite recent gains, access remains a major issue in electricity and, especially, in water and sanitation (particularly in rural areas), and so does performance in local telecom services. Even transport performance appears comparatively less strong than would be expected in an upper middle-income, though more in-depth analysis of comparative performance of transport may be warranted to develop a more nuanced picture, especially across different modes of transport. The main policy implication is that there remain significant needs to scale up infrastructure investments - especially in the yet unserved areas - and improve efficiency in all four major infrastructure sectors if South Africa's infrastructure performance is to catch up with its group of upper middle-income countries.
\end{abstract}

JEL classification: $\mathrm{H} 54, \mathrm{H}, \mathrm{R}, \mathrm{O}, \mathrm{O} 57$

World Bank Policy Research Working Paper 3830, February 2006

The Policy Research Working Paper Series disseminates the findings of work in progress to encourage the exchange of ideas about development issues. An objective of the series is to get the findings out quickly, even if the presentations are less than fully polished. The papers carry the names of the authors and should be cited accordingly. The findings, interpretations, and conclusions expressed in this paper are entirely those of the authors. They do not necessarily represent the view of the World Bank, its Executive Directors, or the countries they represent. Policy Research Working Papers are available online at http://econ.worldbank.org.

Authors: Bogetić is lead economist at the World Bank, Africa Region, Washington D.C. (E-mail: zbogetic@worldbank.org) and Fedderke is professor of economics at the University of Cape Town, School of Economics (E-mail: jfedderk@commerce.uct.ac.za). Research assistance by Atsede AemroSelassie is gratefully acknowledged. 


\title{
International Benchmarking of South Africa's Infrastructure Performance
}

\author{
Željko Bogetić and Johannes W. Fedderke*
}

\section{Introduction}

Infrastructure is back on the priority development agenda of developing countries, especially in SubSaharan Africa. The generally strong association between infrastructure and growth is now well established (e.g., Aschauer 1989; World Development Report 1994). But during the 1990s, underinvestments in infrastructure in Latin America and Sub-Saharan Africa have led to lower economic growth than would otherwise likely be the case (see, for example, Esfahani and Ramirez 2003; and Easterly and Servén 2002). More broadly, infrastructure affects human welfare directly and indirectly via access to and quality of basic services such as water and sanitation, though the impact can differ widely across regions, communities or income groups. Infrastructure is also associated with child health, human capital accumulation and the achievement of the Millenium Development Goals (MDGs) (Leipziger et al. 2003).

In South Africa, infrastructure has been found to strongly affect economic growth (see, for example, Perkins, Fedderke and Luiz 2005; and Fedderke, Perkins and Luiz 2005). In addition, the aging stock of infrastructure against rapidly growing needs has led to renewed emphasis by the government on scaling up infrastructure investments as part of broader policy efforts to lay the foundation for accelerated and pro-poor economic growth and more rapid economic and social integration of the society (see, for example, discussion by Trevor Manuel in South Africa's 2005 budget speech). Effective infrastructure scale-up requires an assessment of performance of various infrastructure sectors. In particular, analyzing international comparative performance can be a useful part of such assessments in order to identify dimensions (quantitative and qualitative) of infrastructure performance where South Africa scores better, on par, or worse than its relevant comparators. This is precisely the contribution of the present paper; in large part, the paper builds on and extends an earlier, preliminary exercise within a broader analysis of infrastructure and growth in South Africa (Bogetić and Fedderke 2005).

The purpose of this paper, therefore, is to systematically benchmark South Africa's infrastructure performance in four major sectors - electricity, water and sanitation, information and communication technology, and transportation - against the relevant group of comparator countries using a new international data base with objective and perception-based indicators of infrastructure performance from over 200 countries. Specifically, we seek to answer a number of relevant questions: How does South Africa compare on major indicators of infrastructure sector performance against the relevant country groups? What do outcome indicators tell us about the relative strengths and weaknesses of South Africa's infrastructure vis-à-vis various income and geographical comparator groups of countries? Where are the largest deviations - positive and negative-from the benchmarks and other comparators? And how does one interpret some of these comparisons to be useful for policy purposes?

\footnotetext{
* Bogetić is lead economist at the World Bank, Africa Region, Washington D.C. (E-mail: zbogetic@worldbank.org) and Fedderke is professor of economics at the University of Cape Town, School of Economics (E-mail: jfedderk@commerce.uct.ac.za). Helpful comments and discussions with Ritva Reinikka, Anton Eberhard, Ioannis Kessides, Luiz Maurer, Antonio Estache, and Cecilia Briceno-Garmendia are gratefully acknowledged. The authors also wish to express gratitude for excellent research assistance by Atsede Aemro-Selassie (World Bank).
} 
The answers to these questions are likely to provide important building blocks towards a more complete assessment of the state of infrastructure in South Africa, its performance, and any need for reform. It would also help frame the ongoing discussion in South Africa in a comparative perspective based on well-defined and widely accepted performance indicators.

The main results suggest the following. Compared to the benchmarks and other country groupings, South Africa's utilities provide solid service at reasonable quality and, in some cases, very competitive prices. Despite recent gains, however, access remains a major issue in electricity and, especially, in water and sanitation (particularly in rural areas where most of the poor reside), and so does performance in local telecom services. Even transport performance appears comparatively less strong than what would be expected in an upper middle-income, though more in-depth analysis of comparative performance of transport may be warranted to develop a more nuanced picture, especially across different modes of transport. The main policy implication is that there remain significant needs to scale up infrastructure investments - especially in the yet unserved areas - and improve efficiency in all four major infrastructure sectors if South Africa's infrastructure performance is to catch up with its group of upper middle-income countries.

The organization of the paper is the following. In the next section, we provide a brief overview of the data, the chosen comparators, and caveats. Then, in the following four sections, we present comparative assessments of the infrastructure performance in electricity, water and sanitation, information and communications technology, and transportation. This is followed by a brief section summarizing some of the larger deviations from the comparator groups of countries along with some reflections on policy implications. The final section provides concluding remarks.

\section{The benchmarking database}

The data used for comparing South Africa's performance comes from the World Bank research data base that was recently developed with a specific objective to be used for this type of benchmarking exercise (Eustache and Goicoechea, 2005). The database pulls together the latest available observations from a number of well documented, specialized data sources that contain more detailed data with longitudinal information. The data base aims to measure sector performance by focusing on sector outcomes - access, affordability/pricing, and quality (technical or perceived). It also provides information on sector institutional reform. Data cover 207 countries (although coverage varies by sector and indicator) ${ }^{1}$ with a limited number of variables ${ }^{2}$ measuring sector outcomes.

For the purpose of benchmarking South Africa, we compare it with all the world geographical comparator groups--Sub-Saharan Africa, OECD, South Asia, East Asia \& Pacific, Middle East \& North Africa, Latin America \& the Caribbean, Europe and Central Asia, and the world-and four groups of countries clustered by level of income per capita - low income, middle income, upper middle income, and OECD countries. Therefore, both region and income level are used as comparator criteria. The main benchmarking group on which much of the analysis is focused is South Africa's per capita income group of upper middle-income countries. Because of the strong association between infrastructure and income level, this is economically the most meaningful group comparator for South Africa. This is supplemented by relevant comparisons with other income groups and major regions of the world to provide a wider, geographical comparison of South Africa's infrastructure performance. Finally, from

\footnotetext{
${ }^{1}$ The percentage of available country observations from the total number of countries (207) varies by indicators from close to $90 \%$ for measures of access to roads, $85-95 \%$ for ICT access and pricing measures, $75-85 \%$ for access to water, and $60 \%$ for access to electricity. The quality indicators generally show lower degrees of completeness than those of access.

${ }^{2}$ The numbers of indicators in each sector are as follows: 7 in energy, 4 in water \& sanitation, 12 in ICT, and 12 in transport.
} 
the aforementioned data base we use the available indicators for electricity (7), water \& sanitation (4), and most of the broader group of indicators for information communication technology (13) and transport (10). For our purpose, the benchmarking is limited to sector performance indicators. Detailed benchmarking is presented in Tables 1-4. We do not use nor discuss institutional reform indicators that are also available in the database, and are subject of a separate exercise.

As with any comparative indicators summarizing performance in a vast number of different countries, interpretation of comparisons must be made carefully and taken with caution. Some of the variations between the indicators may reflect other factors that may make single indicator comparison less revealing, or even misleading. The database itself has its limitations detailed in the cited World Bank analysis by Estache and Goicoechea. ${ }^{3}$ In addition, where appropriate, we explain or qualify how specific circumstances in South Africa may affect a specific indicator comparison. Nevertheless, since the indicators presented here are widely accepted and fairly unambiguous representations of major dimensions of sector performance, we believe that the benchmarking and comparisons are sufficiently meaningful and could prove useful in both analytical and policymaking studies of South Africa's infrastructure performance. Detailed benchmarking for each sector is provided in the Tables 1-6. In the following discussion, we focus on some of the most important conclusions.

\section{Energy-electricity}

Overall assessment. Overall, South Africa's performance in the electricity sector (measured by the seven indicators discussed below) compared to the upper-middle income country benchmark is relatively weak in terms of access, but favorable in terms of technical efficiency (i.e., percentage of losses), pricing, and perceptions of service. The relatively low access reflects in large part the legacy of Apartheid, that left large segments of the population-especially the poor-outside the network of basic service provision. Since 1994, a significant area of policy success has been to increase service access, but the level remains behind the average expectation for upper middle-income countries. Low aggregate losses reflect solid internal technical efficiency of the electricity network, but this hides the problem of occasional outages in specific areas, even in large cities such as Johannesburg. Low prices reflect the comparatively low cost of South Africa's electricity (produced almost exclusively from coal) and the fact that a good part of the capital stock has already been depreciated as there has been little investment in the sector over the past two decades. ${ }^{4}$ Finally, local perceptions of service have been rather favorable, but this may have reflected a selection bias in that only customers that do have service provision responded to this question. The overall picture, therefore, suggests that despite recent gains, the main weakness in South Africa's electricity sector lies in access which remains limited, particularly in terms of service delivery to the poor (Table 1 and Figures 1-2).

Access. Not surprisingly, South Africa's access to the electricity network is superior to the rest of Sub-Saharan Africa (SSA) with $66 \%$ of the population having access, compared to $15 \%$ for region as a whole..$^{5}$ Access has also risen substantially in South Africa, from some $30 \%$ ten years ago reflecting the success to date of the policy of widening access to the electricity network. Nevertheless, South Africa's level of overall access remains significantly behind-by about a

\footnotetext{
${ }^{3}$ For example, the database reports the latest information available between 1997 and 2002, corresponding to arithmetic averages of available data. In some cases, more recent within country information may be available that is not yet reflected in the database. Also, efforts to weight the raw data by population could help enhance the quality of the cross-country comparisons.

${ }^{4}$ With significant new investments being planned by ESKOM over the coming years, prices are likely to increase.

5 The database observation for South Africa is from 2002. More recent country data suggests an access rate of $70 \%$ (UNDP/WorldBank 2005), but the overall conclusion remains the same.
} 
third-its own income group of upper middle-income countries (87\%). A related (and corroborating) statistic focusing on households indicates that about $65 \%$ of all households in South Africa report having access to electricity compared to $23 \%$ for the SSA region and $74 \%$ upper middle-income countries. Compared with other regions of the world, South Africa performs better than South Asia and East Asia Pacific.

Affordability-pricing. South African average end-user prices (US cents/kwh) are one of the cheapest in the world at 3 cents for residential and 2 cents for non-residential customers. By comparison, these user prices in upper middle income countries are, on average, about 9 and 7 cents, respectively, while SSA rates are 6 and 5 cents. The world average is 9 cents for residential customers and 6 cents for non-residential customers. In South Africa, the low user prices do not seem to reflect obvious, overall underpricing, as is the case in many developing countries with the attendant quasi-fiscal losses. Instead, it is a consequence of the low cost structure of what is considered a well-run state electricity company (ESKOM) and the fact that part of the capital stock has already been depreciated as there has been little investment in the sector over the past two decades; hence, the fixed cost component of the electricity cost/price in South Africa is very low. ${ }^{6}$

Quality-technical. Measured by the percentage of aggregate transmission and distribution losses, technical efficiency of the electricity sector is strong. Electric power transmission and distribution losses account for $8 \%$ of total output in South Africa, which outperforms both SSA $(19 \%)$ and upper middle income countries (14\%). Indeed, this aggregate performance is more comparable to the high-income group of OECD countries $(6 \%)$. However, this aggregate picture must be qualified: for the $30 \%$ of the population not having access, this aggregate technical efficiency does not matter. In addition the increased prevalence of power outages in specific communities, even within Johannesburg, associated with the poor maintenance and the state of the distribution network under the control of local governments further qualifies the technical efficiency of the distribution network. ${ }^{7}$

Quality-perceptions. In terms of commercial perception of electricity service, South Africa ranks amongst the best with a 5.8 rating out of 7 ( $7=$ best, $1=$ worst). This compares favorably with high income OECD countries (6.3) and is higher than upper middle income countries (5.2). South Africa also performs well on commercial perception of the public agency electricity provider with a ranking of 6 out of 7 . This ranking is only matched by Middle East and North Africa (MENA) and is higher than upper middle income (5.3) and high income OECD (5.3). As noted above, however, this may reflect a selection bias in that only customers with access to service would normally respond to this question. In that sense, the indicators of the lack of access (about $34 \%$ of the population) and the generally favorable perceptions of service cover essentially different segments of the population.

\footnotetext{
6 However, this static picture is going to change soon. The South African rates are likely to increase over the coming years as the electricity company, ESKOM, implements its major investment upgrading program aimed at rehabilitating and expanding its existing capacity and the distribution network. Part of the financing of this investment program will need to come from increased rates to accommodate higher fixed costs arising from the new investments. When it comes to pricing, this will require careful thought to the rebalancing/design of tariffs to balance the objectives of access, efficiency, revenue and affordability.

${ }^{7}$ In South Africa, about half of the distribution network is under the control of the main utility ESKOM, and the rest is under the control of local governments. Since the local governments face major expenditure pressures against limited revenue sources available, maintenance of their electricity distribution network has often been inadequate.
} 
Table 1: Benchmarking of South Africa's Performance in the Energy Sector

\begin{tabular}{|c|c|c|c|c|c|c|c|c|c|c|c|c|}
\hline Energy & $\begin{array}{l}\text { South } \\
\text { Africa }\end{array}$ & $\begin{array}{l}\text { Upper } \\
\text { Middle } \\
\text { Income }\end{array}$ & SSA & $\begin{array}{c}\text { Middle } \\
\text { East } \\
\text { and } \\
\text { Noth } \\
\text { Africa } \\
\end{array}$ & $\begin{array}{l}\text { South } \\
\text { Asia }\end{array}$ & $\begin{array}{c}\text { East } \\
\text { Asia } \\
\text { Pacific }\end{array}$ & $\begin{array}{c}\text { Latin } \\
\text { America } \\
\& \\
\text { Caribbean }\end{array}$ & $\begin{array}{c}\text { Europe } \\
\& \\
\text { Central } \\
\text { Asia }\end{array}$ & $\begin{array}{c}\text { Low } \\
\text { Income }\end{array}$ & $\begin{array}{l}\text { Middle } \\
\text { Income }\end{array}$ & $\begin{array}{c}\text { High } \\
\text { Income } \\
\text { OECD }\end{array}$ & World \\
\hline $\begin{array}{l}\text { Access to Electricity Network } \\
\text { (\% of Population) }\end{array}$ & 66 & 87 & 15 & 88 & 31 & 54 & 79 & 99 & 31 & 85 & .. & 60 \\
\hline $\begin{array}{l}\text { Households Reporting Access to Electricity } \\
\text { (\% of households) }\end{array}$ & 65 & 74 & 23 & 80 & 39 & 62 & 72 & 99 & 32 & 79 & .. & 45 \\
\hline $\begin{array}{l}\text { Energy Use Per PPP GDP } \\
\text { (kg of oil equivalent/1000 PPP dollars, Constant 2000) }\end{array}$ & 257 & 249 & 364 & 249 & 184 & 212 & 207 & 375 & 374 & 246 & 188 & 275 \\
\hline $\begin{array}{l}\text { Electricity Average End-User Prices (US cents/kWh) - } \\
\text { (Residential/Non-Residential) }\end{array}$ & $3 / 2$ & $9 / 7$ & $6 / 5$ & .. & .. & $5 / 5$ & $10 / 8$ & $6 / 6$ & $6 / 6$ & $8 / 7$ & $13 / 6$ & $9 / 6$ \\
\hline $\begin{array}{l}\text { Commercial Perception of Electricity service } \\
\text { (1=worst } 7=\text { =est) }\end{array}$ & 5.8 & 5.2 & 4.3 & 5.1 & 2.6 & 4.3 & 4.2 & 4.8 & 2.8 & 4.7 & 6.3 & 5.0 \\
\hline $\begin{array}{l}\text { Commercial Perception of Public Agency Electricity Provider } \\
\text { (1=worst } 7=\text { best) }\end{array}$ & 6.0 & 5.3 & 4.3 & 6.0 & 3.8 & 5.0 & 4.8 & 4.8 & 4.0 & 5.2 & 5.3 & 4.8 \\
\hline $\begin{array}{l}\text { Electric Power Transmission and Distribution Losses } \\
\text { (\% of total output) }\end{array}$ & 8.0 & 14.0 & 19.0 & 14.0 & 22.0 & 12.0 & 18.0 & 18.0 & 22.0 & 15.0 & 6.0 & 14.0 \\
\hline
\end{tabular}

Note: Data used is from the latest observation available between 1997 and 2003 .

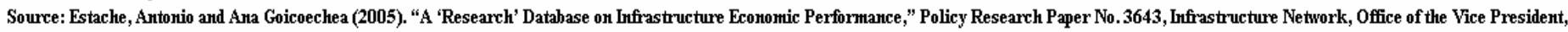
June 2005.
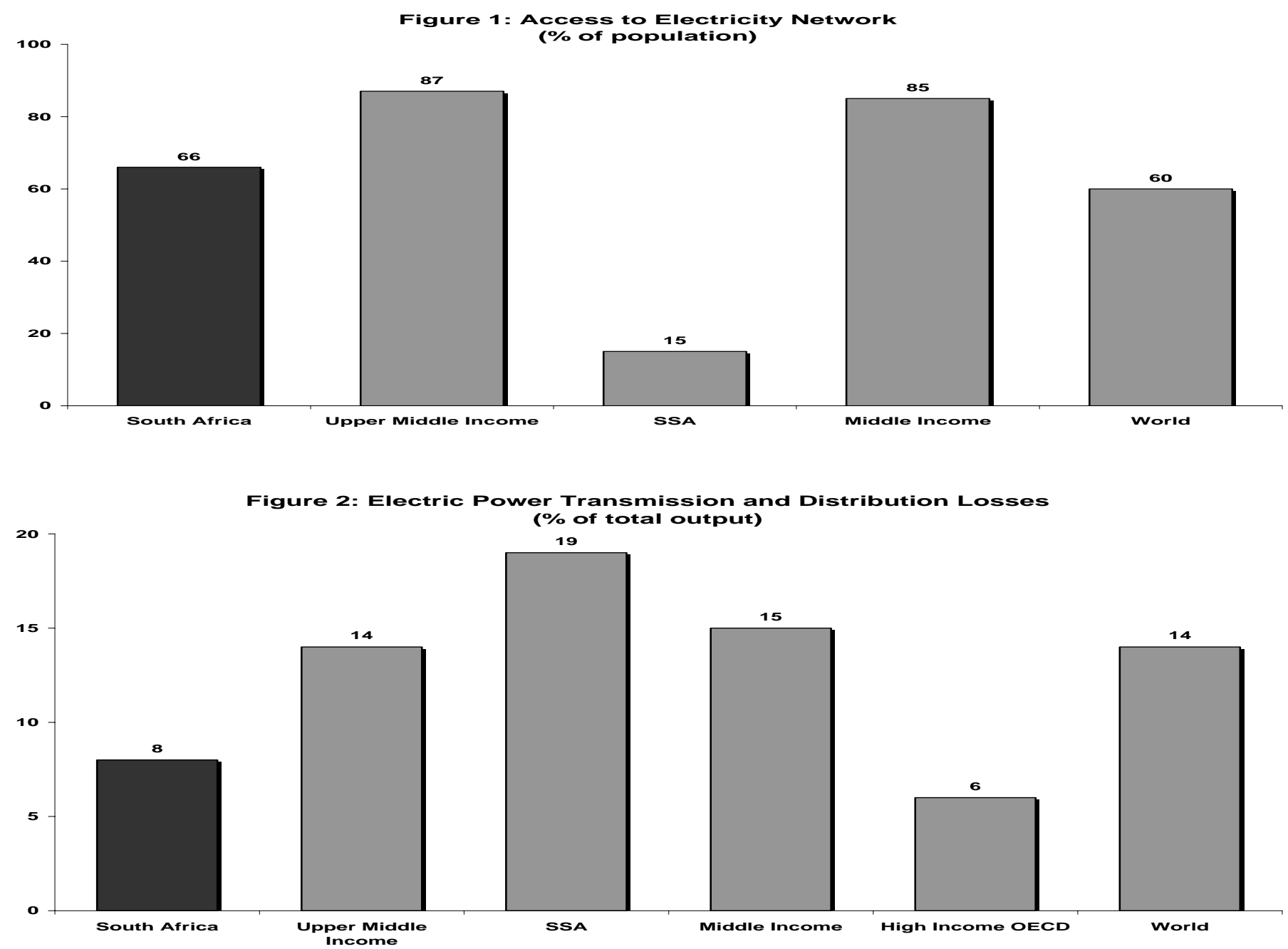


\section{Water \& sanitation}

Overall assessment. Overall, South Africa's performance in access to water lags behind its benchmark upper middle-income group, essentially because of the much lower access in rural areas. This is even more notable with respect to sanitation. In terms of the overall average, the quality of drinking water as measured by the percentage of households using piped or welled water in the aggregate is better than in its benchmark group, but this is because of the very high performance on this indicator in urban areas. (The database does not have information on affordability/pricing). By contrast, rural households score lower than the benchmark and also lower than almost all world regions, including Sub-Saharan Africa. Apparently, while access and quality do not appear to be major problems in urban areas, the performance in these dimensions in rural areas lags seriously behind most comparator groups. This favorable urban picture should also be qualified by the fact that in South Africa, some communities in urban areas, referred to as "peri-urban" areas (e.g., parts of Soweto, Diepsloot etc.) that may or may not belong formally or statistically to their larger urban agglomerations, often lack quantity and quality of basic service, such as water and sanitation (Table 2 and Figures 3-4).

Access. Overall access to water is below the benchmark upper middle-income countries, because of the significantly lower access in rural areas. Specifically, population with access to improved water is $87 \%$, which is significantly higher than SSA (64\%) but lags behind upper middle-income countries (93\%). South Africa compares well to the broader group of middleincome countries (both lower and upper middle income) (89\%), but is noticeably below high income OECD (99\%). However, looking at the rural/urban differences, rural South Africa (73\%) lags far behind the upper middle income rural average (85\%), while South African urban areas $(98 \%)$ do better than other upper middle-income countries $(96 \%)$. About $67 \%$ of the population has access to improved sanitation, which is almost twice the SSA level and slightly above the world average (64\%). However it is still far behind upper middle-income countries $(86 \%)$ and high-income OECD countries $(100 \%)$.

Quality-technical. The percentage of households using piped or welled water as main source of drinking water is 85 for South Africa, which is higher than in upper middle income group (82\%), East Asia and Pacific (80\%), and SSA (78\%), but below both Middle East \& North Africa (89\%) and South Asia (89\%). Once again, however, this figure masks a stark contrast between urban and rural areas. The share of rural households in South Africa using piped or welled water as main source of drinking water is only $65 \%$ compared to $98 \%$ for urban areas. Significantly, the rural area percentage for South Africa is lower than the comparable rural household percentages in all the world regions, including SSA (71\%), except for East Asia \& Pacific and Latin America $\&$ the Caribbean which have very similar performance $(64 \%$ each); the latter is the region that has been documented as having a significant backlog of infrastructure deficiencies that, inter alia, contributed to its low growth (Leipziger, 2001). By contrast, South Africa's performance on this indicator in urban areas (98\%) is the highest (together with South Asia) among all world regions and low and middle income countries.

Quality-perception. At 5.7 out of 7, South Africa gets one of the highest ratings in commercial perception of water service. The rating for high income OECD countries is 5.2 and SSA (4.2). Again, this may represent the view of the satisfaction with service by the segments of the population already enjoying access. Also, it may reflect the "urban bias" of the perception indicator, and may hide differences between the quality of service in urban versus rural communities (see section on urban-rural divide below). 
Table 2: Benchmarking of South Africa's Performance in the Water \& Sanitation

\begin{tabular}{|c|c|c|c|c|c|c|c|c|c|c|c|c|}
\hline Water & $\begin{array}{l}\text { South } \\
\text { Africa }\end{array}$ & $\begin{array}{l}\text { Upper } \\
\text { Middle } \\
\text { Income }\end{array}$ & SSA & $\begin{array}{c}\text { Middle } \\
\text { East } \\
\text { and } \\
\text { Noth } \\
\text { Africa } \\
\end{array}$ & $\begin{array}{l}\text { South } \\
\text { Asia }\end{array}$ & $\begin{array}{c}\text { East } \\
\text { Asia } \\
\text { Pacific }\end{array}$ & $\begin{array}{c}\text { Latin } \\
\text { America } \\
\& \\
\text { Caribbean }\end{array}$ & $\begin{array}{c}\text { Europe } \\
\& \\
\text { Central } \\
\text { Asia }\end{array}$ & $\begin{array}{c}\text { Low } \\
\text { Income }\end{array}$ & $\begin{array}{l}\text { Middle } \\
\text { Income }\end{array}$ & $\begin{array}{c}\text { High } \\
\text { Income } \\
\text { OECD }\end{array}$ & World \\
\hline $\begin{array}{l}\text { Access to Improved Water Sources } \\
(\% \text { of population) }\end{array}$ & 87 & 93 & 64 & 85 & 72 & 75 & 90 & 87 & 65 & 89 & 99 & 80 \\
\hline $\begin{array}{l}\text { Access to Improved Sanitation } \\
(\% \text { of population })\end{array}$ & 67 & 86 & 37 & 77 & 48 & 60 & 77 & 78 & 41 & 79 & 100 & 64 \\
\hline $\begin{array}{l}\text { Commercial Perception of Water Service } \\
\text { (1=worst } 7=\text { best })\end{array}$ & 5.7 & 5.0 & 4.2 & 5.6 & 4.1 & 4.8 & 4.7 & 4.6 & 4.0 & 4.9 & 5.2 & 4.7 \\
\hline $\begin{array}{l}\text { Households Using Piped or Well Water as Main Source of } \\
\text { Drinking Water (\% of households) }\end{array}$ & 85 & 80 & 78 & 89 & 90 & 74 & 75 & 83 & 78 & 81 & .. & 79 \\
\hline
\end{tabular}

Note: Data used is from the latest observation available between 1997 and 2003.

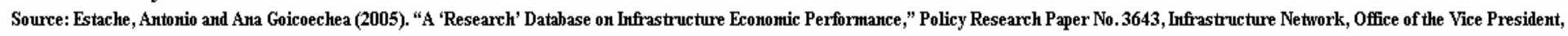
June 2005.

Figure 3: Access to Impoved Water Sources

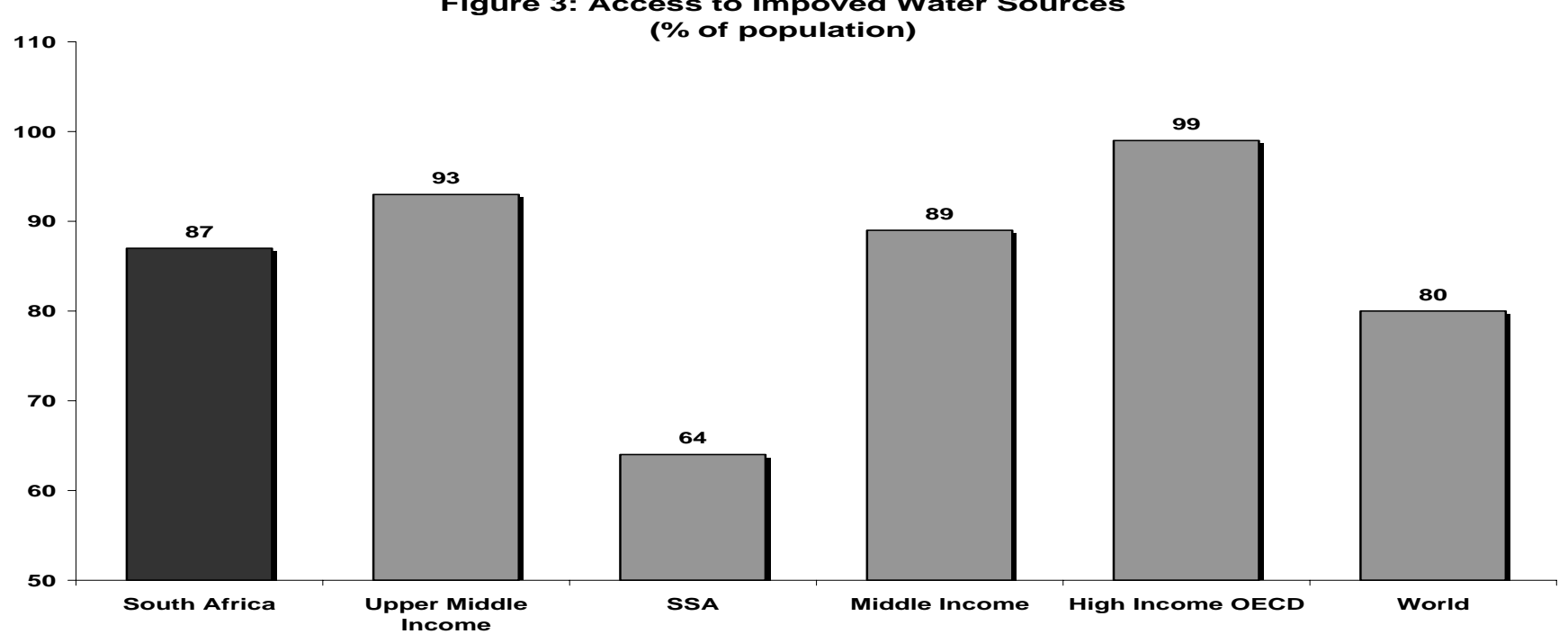

Figure 4: Households Using Piped or Well Water as Main Source of Drinking

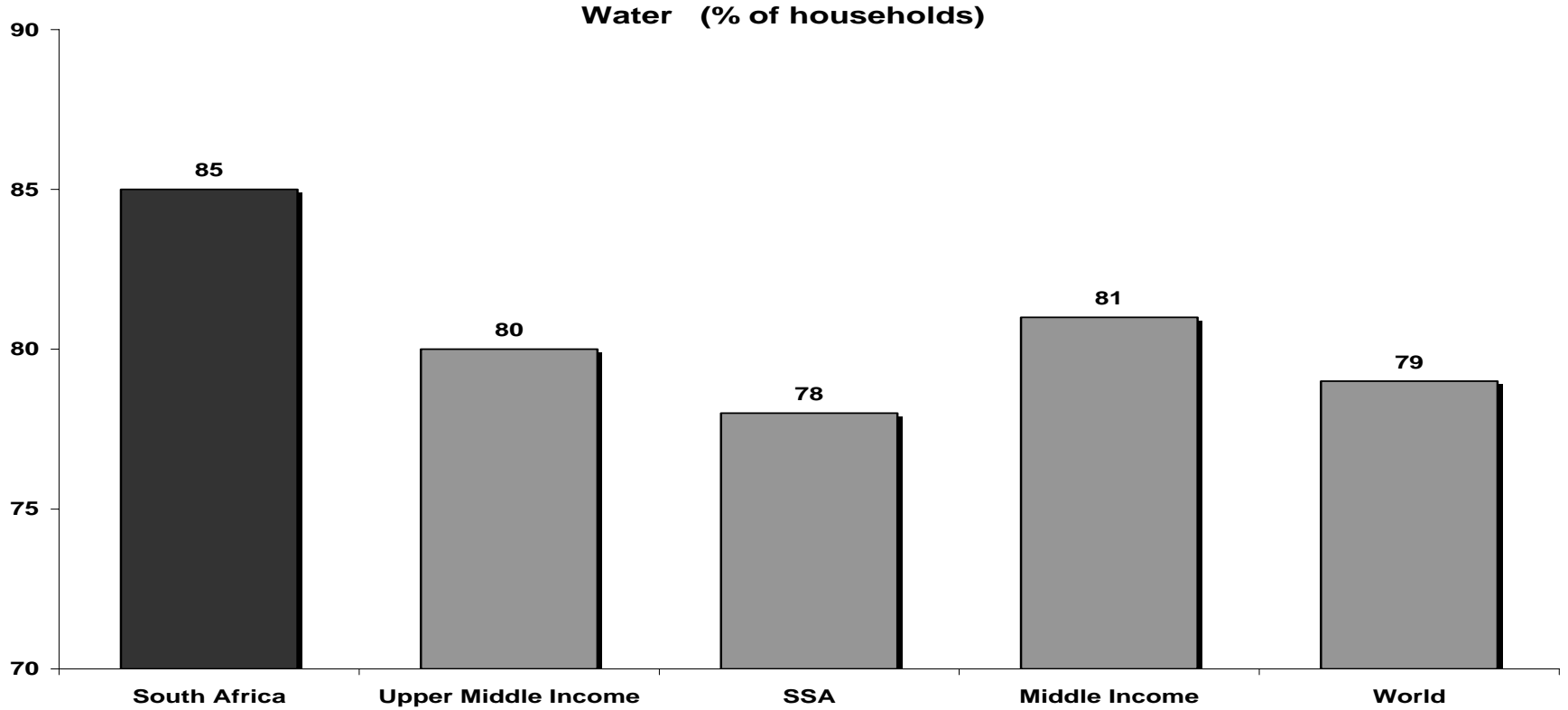




\section{Information and Communications Technology (ICT)}

Overall assessment. In general, the ICT sector in South Africa displays performance akin to that of the energy and water \& sanitation sectors, with some interesting nuances emerging from the pricing of various services. At first glance, the overall indicator of access appears good, but supplementary indicators suggest less than expected quality and major gaps in service delivery, quality and even access in rural areas. For example, on the surface, South African households pay some of the highest local rates in the world, and the low affordability is reflected in low telephone ownership in rural areas. By contrast, off-peak cellular service and international calls to the United States are provided at low, competitive prices, catering largely the wealthier segments of the population. But this has to be qualified. The poor segments of the population may now be effectively by-passing the land-line network, and are switching straight into the cellular network. So the lower rates may not be exclusively benefiting the wealthy. (See the discussion below on the perception of cellular access.) Nevertheless, in the local debate on the cost issue, there are indications that high international prices prevail for calls to many other destinations, and that broadband access is both limited and expensive. ${ }^{8}$ Moreover, quality, as measured by reported faults per year per 100 mainlines, appears surprisingly low for an upper middleincome country (Table 3 and Figures 5-6).

Access. In terms of mainline teledencity, the picture is similar to energy and water whereby South Africa has better penetration than SSA, Middle East \& North Africa, South Asia, and East Asia Pacific countries but lags somewhat behind middle income countries and Latin America \& the Caribbean. However cellular teledencity is reasonably comparable to upper middle-income countries though it still lags behind high-income OECD levels. In terms of household ownership of telephones, only $28 \%$ of South African households own a telephone, which is much higher than the upper middle-income benchmark of 13\% and comparable figures for SSA and South Asia regions, both at 4\%, and East Asia Pacific (9\%). But it is still a long way from Europe and Central Asia (ECA) at 43\%, suggesting considerable remaining room for growth. The ownership rates in rural areas, however, are seven times lower $(6 \%)$ than in urban areas $(43 \%)$ in South Africa, making the rural rate more comparable to those in entire group of middle-income countries.

Affordability-pricing. A 3-minute local call in U.S. cents is one of the most expensive in the world in South Africa at 15 cents, which is three times the cost in South Asia and East Asia Pacific and equal to the high-income OECD countries. This reflects monopolistic market structures in local services. Local debate in South Africa has also emphasized the high cost structure, including on the international call market segment. Nevertheless, within the cellular and international segment, some calls are very competitive. For example, the database used for this benchmarking shows that in terms of the cost of three off-peak minute cellular local calls ( 25 cents), South Africa has one of the cheapest rates when compared with upper middle-income (54 cents) and high-income OECD (59 cents) countries where costs are twice as much. In addition, according to the database (with original data from the ITU-World Telecommunications Development Report) an international, 3-minute, peak rate, fixed line call to the United States in 2001 appeared lower than in upper middle-income countries and high-income OECD countries, but this needs to be checked against most recent data within the country and a more detailed look at the rate structure before making definitive conclusions.

\footnotetext{
${ }^{8}$ See Truen and Hodge (2005).
} 
Quality-technical. Reported faults per 100 telephone mainlines (per year) are very high (48) by upper middle- income (18) country standards and are closer to the SSA average (57). High income OECD country rates - towards which South Africa may aspire in this highly globalized sector--are more than four times lower (11\%).

Quality-perception. Interestingly, perceptions of ICT are more closely aligned to the other indicators of performance. Commercial perception of telephone infrastructures rating is 5.1 out of 7 compared to 6.6 for high income OECD countries and 5.6 in upper middle income countries. Commercial perception of availability of mobile telephones is much higher at 6.3 (vs. 6 for upper middle income), which is only better in high income OECD at 6.6. Commercial perception of internet access in schools is also low by high income OECD standards, 3.6 vs. 5.4 and slightly lower than upper middle-income countries (3.8). Commercial perception of postal efficiency is even worse at 3.3 which is only just above the average for low income countries (3.1), and almost half the rating given to high income OECD, and compared to 4.4 for upper middle income countries.

Table 3: Benchmarking of South Africa's Performance in the ICT Sector

\begin{tabular}{|c|c|c|c|c|c|c|c|c|c|c|c|c|}
\hline ICT & $\begin{array}{l}\text { South } \\
\text { Africa }\end{array}$ & $\begin{array}{l}\text { Upper } \\
\text { Middle } \\
\text { Income }\end{array}$ & SSA & $\begin{array}{c}\text { Middle } \\
\text { East } \\
\text { and } \\
\text { Noth } \\
\text { Africa } \\
\end{array}$ & $\begin{array}{l}\text { South } \\
\text { Asia }\end{array}$ & $\begin{array}{c}\text { East } \\
\text { Asia } \\
\text { Pacific }\end{array}$ & $\begin{array}{c}\text { Latin } \\
\text { America } \\
\& \\
\text { Caribbean }\end{array}$ & $\begin{array}{c}\text { Europe } \\
\& \\
\text { Central } \\
\text { Asia }\end{array}$ & $\begin{array}{c}\text { Low } \\
\text { Income }\end{array}$ & $\begin{array}{l}\text { Middle } \\
\text { Income }\end{array}$ & $\begin{array}{l}\text { High } \\
\text { Income } \\
\text { OECD }\end{array}$ & World \\
\hline $\begin{array}{l}\text { Teledensity } \\
\text { (total telephone subscribers/1000 people) }\end{array}$ & 408 & 635 & 99 & 292 & 72 & 172 & 433 & 547 & 64 & 468 & 1393 & 501 \\
\hline $\begin{array}{l}\text { Mainlines Teledensity } \\
\text { (mainlines subscribers/1000 people) }\end{array}$ & 107 & 261 & 31 & 129 & 35 & 76 & 192 & 224 & 29 & 193 & 572 & 213 \\
\hline $\begin{array}{l}\text { Cellular Teledensity } \\
\text { (cellular subscribers/1000 people) }\end{array}$ & 364 & 381 & 73 & 167 & 37 & 96 & 249 & 325 & 37 & 280 & 827 & 296 \\
\hline $\begin{array}{l}\text { Households with Own Telephone } \\
\text { (\% of households) }\end{array}$ & 28 & 13 & 4 & 24 & 4 & 9 & 23 & 43 & 6 & 22 & .. & 13 \\
\hline $\begin{array}{l}\text { Cost of Local Phone Call } \\
\text { (US cents } / 3 \text { minutes) }\end{array}$ & 15 & 9 & 10 & 6 & 4 & 5 & 7 & 7 & 8 & 7 & 15 & 9 \\
\hline $\begin{array}{l}\text { Cost of Phone Call to the US } \\
\text { (US cents } / 3 \text { minutes) }\end{array}$ & 58 & 305 & 497 & 281 & 336 & 450 & 325 & 326 & 504 & 309 & 128 & 335 \\
\hline $\begin{array}{l}\text { Cost of Cellular Local Call } \\
\text { (US cents } / 3 \text { off-peak minutes) }\end{array}$ & 25 & 54 & 42 & 52 & 17 & 42 & 57 & 40 & 40 & 49 & 57 & 49 \\
\hline $\begin{array}{l}\text { Commercial Perception of Telephone/Fax Infrastructure } \\
\text { quality (1=worst } 7=\text { best) }\end{array}$ & 5.1 & 5.6 & 4.3 & 5.8 & 4.3 & 5.2 & 4.6 & 5.3 & 3.4 & 5.3 & 6.6 & 5.5 \\
\hline $\begin{array}{l}\text { Commercial Perception of Availability of Mobile or Cellular } \\
\text { Telephone } \quad(1=\text { worst } 7=\text { best) }\end{array}$ & 6.3 & 6.0 & 5.7 & 5.9 & 5.9 & 5.7 & 5.5 & 6.0 & 5.0 & 5.9 & 6.7 & 6.1 \\
\hline $\begin{array}{l}\text { Commercial Perception of Intemet Access in Schools } \\
(1=\text { worst } 7=\text { best })\end{array}$ & 3.6 & 3.8 & 2.8 & 3.5 & 2.7 & 3.4 & 2.8 & 3.7 & 2.1 & 3.4 & 5.4 & 4.0 \\
\hline $\begin{array}{l}\text { Commercial Perception of Postal Efficiency } \\
(1=\text { worst } 7=\text { best })\end{array}$ & 3.3 & 4.4 & 3.7 & 4.9 & 3.3 & 4.2 & 3.1 & 4.3 & 3.1 & 3.9 & 6.2 & 4.6 \\
\hline $\begin{array}{l}\text { Phone Faults } \\
\text { (reported faults/100 mainlines) }\end{array}$ & 48 & 18 & 57 & 23 & 97 & 39 & 24 & 34 & 64 & 25 & 11 & 37 \\
\hline $\begin{array}{l}\text { Unmet Demand } \\
(\% \text { of main telephone lines in operation) }\end{array}$ & 1 & 4 & 50 & 26 & 24 & 13 & 17 & 8 & 47 & 12 & 0 & 21 \\
\hline
\end{tabular}

Note: Data used is from the latest observation available between 1997 and 2003.

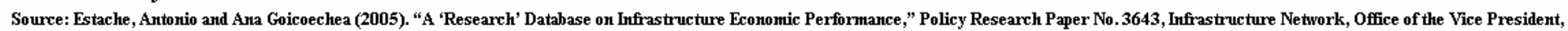
June 2005. 
Figure 5: Teledensity

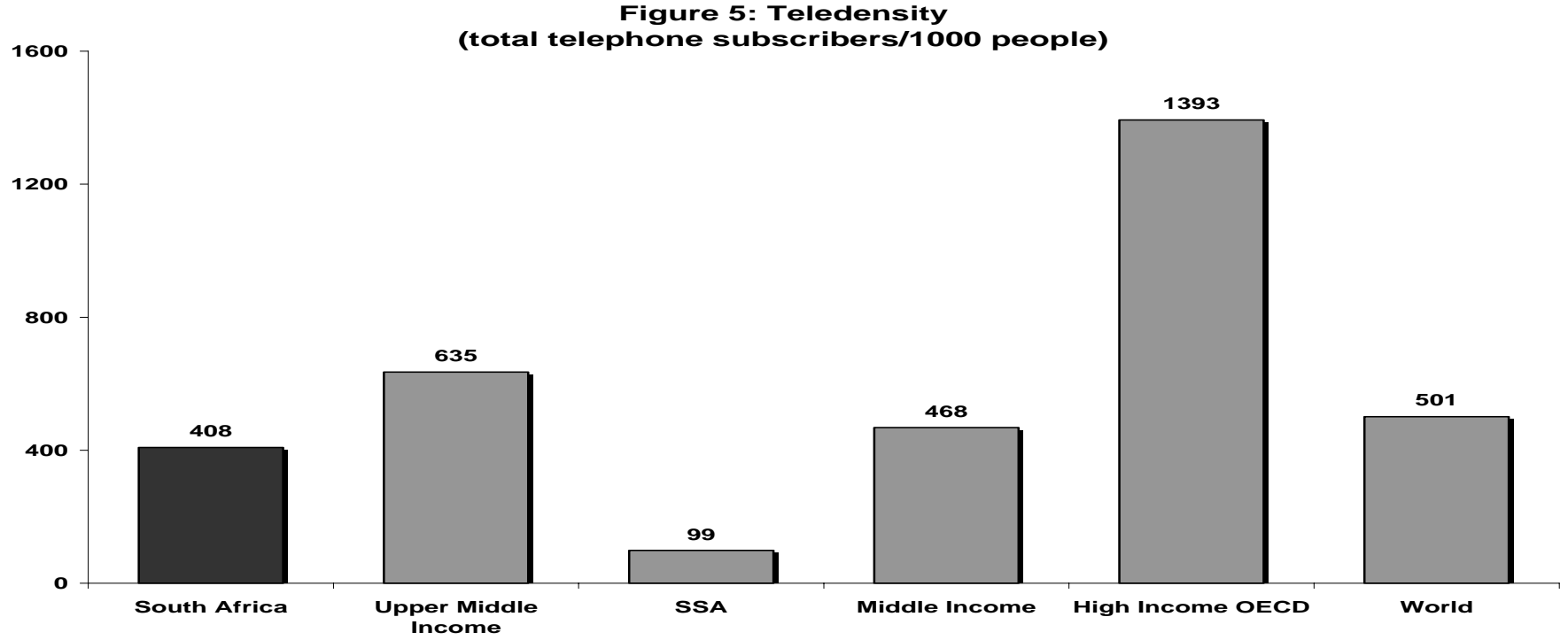

Figure 6: Phone Faults

(reported faults/100 mainlines)

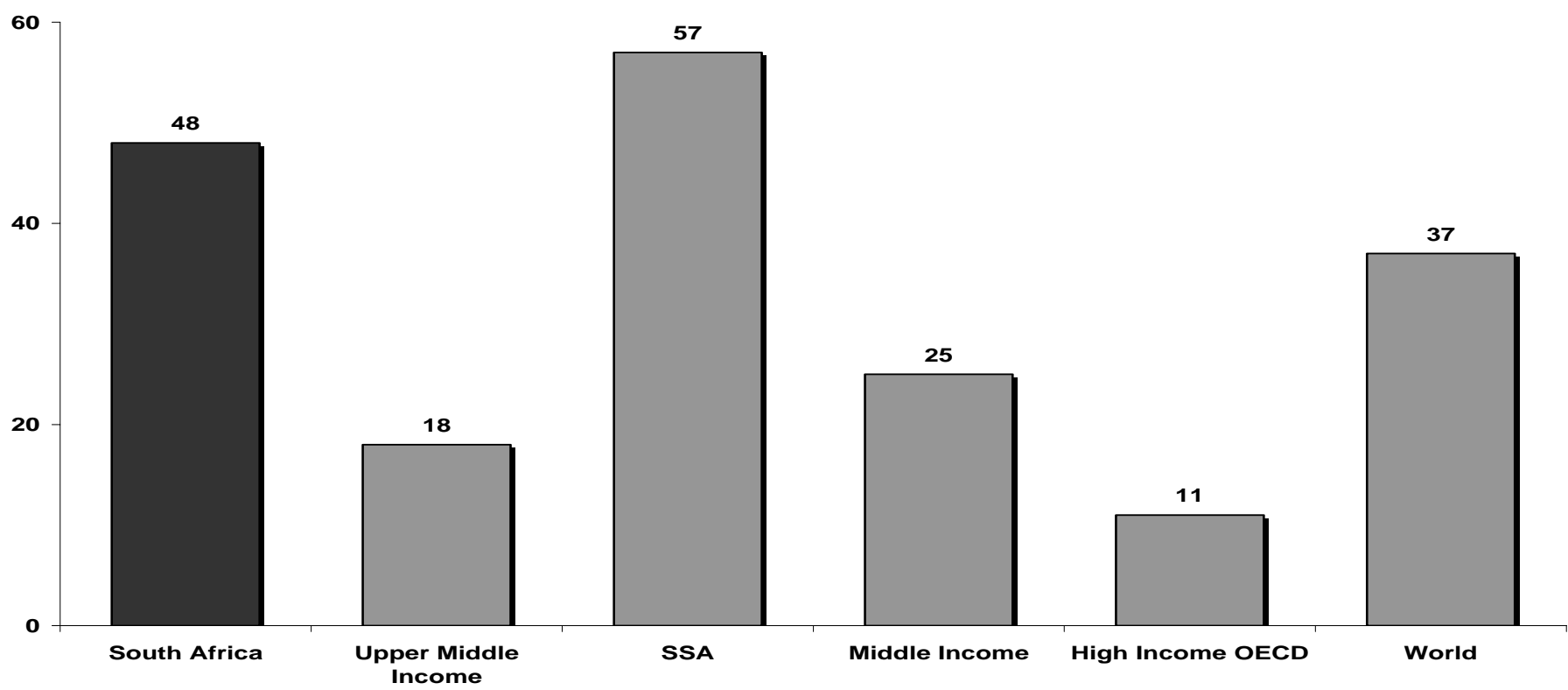

\section{Transport}

Overall assessment. The transport sector's overall performance indicators show South Africa lagging behind its comparator country groups and several other regions. This finding must be taken with caution though, reflecting at least two factors at play. First, it may simply reflect a more idiosyncratic territorial distribution of population and economic activity in a large, coastal, resource rich country such as South Africa than is the case for the average country group. Second, it may reflect some peculiarities in the type of road network that is appropriate for a country with semi-arid climate, and with a large proportion of its land surface carrying low population densities. However, it also reflects the legacy of the Apartheid era and wide inequalities in infrastructure service delivery between the privileged group and the majority of the population. Perceptions of the quality of service delivery are relatively favorable (Table 4 and Figures 7-8). 
Access. Road density in terms of population (road-kilometers per 1,000 people) is twice the average for low income countries and higher than Middle East \& North Africa, and East Asia Pacific. However, at 6.1 road-km per 1000 people it is only a third of the density of high income OECD countries and two-thirds of upper-middle income countries. Interestingly, Brazil has significantly higher road density in terms of population (10), while Indonesia and Malaysia score lower (1.7 and 2.8). Road density in terms of land (road-kilometers per 1,000 sq km) is low (227) when compared with many other groups and is only higher than that of SSA (155) and low income countries (181). It is much lower than in benchmark upper middle-income countries (328). At the same time, it is important to recognize that these road density indicators for South Africa may be somewhat misleading in comparative perspective because of the specific territorial configuration of population density that is concentrated in comparatively small parts of an otherwise large national territory. To the extent that South Africa has lower than average population density and greater differences in the concentration of population and economic activity (parts of the country are very poorly inhabited with very little or no commercial activity) in different regions, the indicator may overstate the gap with comparator countries. For example, South Africa performance on density in terms of land appears similar to Brazil (203 road kilometers per $1,000 \mathrm{sq} \mathrm{km})$ ), another resource rich, coastal country with vast segments of the territory sparsely populated; similarly Indonesia and Malaysia also have very similar road density in terms of land (203 and 200 road kilometers per $1,000 \mathrm{sq} \mathrm{km}$, respectively). ${ }^{9}$ Rail lines density in terms of population, by contrast, is very high when compared to SSA, Middle East \& North Africa, South Asia, East Asia Pacific, and Latin America \& the Caribbean. It is slightly higher than the average for all middle income and just below the benchmark upper-income group. South Africa' rail lines density in terms of land, however, is far behind those in middle income and high income countries and is also behind South Asia but ahead of other groups. Similar qualification for the interpretation of road densitiy applies here as well.

Quality-technical. According to the database, South Africa has one of the lowest percentages of paved roads at $21 \%$. This is lower than SSA $(25 \%)$ and low income countries $(30 \%)$ and far behind upper middle income (57\%) and high income countries $(82 \%)$. This may reflect the legacy of the strong urban bias and the economic configuration of economic activity inherited from the Apartheid era. Four important caveats are in order here. First, local information on paved roads show a higher percentage (31\%) that was already achieved in 1994 (Perkins et al. 2005); as of writing, we could not reconcile this with the number from the benchmarking database that on this indicator originates in the World Bank's World Development Report 2004. But even if the $31 \%$ figure is taken at face value, while it would imply better performance in South Africa than in SSA region, it would remain worse than in upper middle-income countries. Second, the quality of the paved roads variable itself probably hides considerable cross-country variation: paved roads in South Africa may be of higher quality than those in most SSA countries, but this variation would presumably be much less relevant for the upper middleincome group. Third, the proportion of roads paved may hide a relatively well developed road network in terms of road kilometers (thus inflating the denominator of the proportion), though the preceding discussion puts some limits on this possibility. Fourth, given the semi-arid climate of South Africa, and the low population densities in large parts of South Africa's geography, it is not clear what the optimal pave roads proportion might be. Nevertheless, irrespective of which proportion is used $(21 \%$ or $31 \%)$, we note that that South Africa reports a lower proportion than

\footnotetext{
${ }^{9}$ Euchache and Goicoechea (2005), Table A4-2, pp. 105-07.
} 
its benchmark group of upper middle-income countries, and significantly lower than highincome OECD countries.

Quality-perception. South Africa has one of the longest travel times to work in main cities (35 minutes) when compared to upper middle income (29 minutes), high income OECD (32 minutes) and SSA (34 minutes) although the difference is small. The world average is 31 minutes. While the small difference makes it difficult to infer much of this comparison, the long commutes in South Africa may also reflects the inherited road network from the pre-1994 era that now results in the majority of the population often facing long and costly commutes; in some communities, commuting costs may reach prohibitive levels as proportion of the prospective wage, thereby discouraging job search and earning opportunities for the poor. ${ }^{10}$ Commercial perception of service delivered by the roads department is one of the highest in the world at 5.3, only bettered by MENA at 5.5. The average for high income OECD countries is 4.3. Commercial perception of ports facilities and railroad services are lower than for roads but are still much higher than low and middle income countries and are not too far behind the ratings of high income OECD countries. Commercial perception of air transport services gets the highest ranking of all transport sectors at 5.6, which compares well with 5.7 for high income OECD countries.

Table 4: Benchmarking of South Africa's Performance in the Transport Sector

\begin{tabular}{|c|c|c|c|c|c|c|c|c|c|c|c|c|}
\hline Transport & $\begin{array}{l}\text { South } \\
\text { Africa }\end{array}$ & $\begin{array}{l}\text { Upper } \\
\text { Middle } \\
\text { Income }\end{array}$ & SSA & $\begin{array}{c}\text { Middle } \\
\text { East } \\
\text { and } \\
\text { Noth } \\
\text { Afiica } \\
\end{array}$ & $\begin{array}{l}\text { South } \\
\text { Asia }\end{array}$ & $\begin{array}{c}\text { East } \\
\text { Asia } \\
\text { Pacific }\end{array}$ & $\begin{array}{c}\text { Latin } \\
\text { America } \\
\& \\
\text { Caribbean }\end{array}$ & $\begin{array}{c}\text { Europe } \\
\& \\
\text { Central } \\
\text { Asia }\end{array}$ & $\begin{array}{l}\text { Low } \\
\text { Income }\end{array}$ & $\begin{array}{l}\text { Middle } \\
\text { Income }\end{array}$ & $\begin{array}{l}\text { High } \\
\text { Income } \\
\text { OECD }\end{array}$ & World \\
\hline $\begin{array}{l}\text { Road Density in Terms of Population } \\
\text { (road-km/1000 people) }\end{array}$ & 6.1 & 9.2 & 3.3 & 4.8 & 2.4 & 4.2 & 5.7 & 8.6 & 3.0 & 7.0 & 17.3 & 6.7 \\
\hline $\begin{array}{l}\text { Road Density in Terms of Land } \\
\text { (road-km/1000 sq km) }\end{array}$ & 227 & 1076 & 156 & 609 & 545 & 276 & 713 & 580 & 181 & 702 & 1340 & 841 \\
\hline $\begin{array}{l}\text { Rail Lines Density in Terms of Population } \\
\text { (rail-km/1000 people) }\end{array}$ & 0.44 & 0.51 & 0.18 & 0.1 & 0.05 & 0.14 & 0.33 & 0.47 & 0.13 & 0.4 & 0.53 & 0.33 \\
\hline $\begin{array}{l}\text { Rail Lines Density in Terms of Land } \\
\text { (rail-km/1000 sq km) }\end{array}$ & 16.5 & 31.3 & 3.7 & 5.5 & 18.8 & 8.9 & 14.8 & 33.2 & 9.3 & 23.3 & 46.2 & 23.1 \\
\hline $\begin{array}{l}\text { Travel Time to Work in Main Cities } \\
\text { (minutes/one-way work trip) }\end{array}$ & 35 & 29 & 34 & 25 & 27 & 36 & 29 & 29 & 33 & 29 & 32 & 31 \\
\hline $\begin{array}{l}\text { Commercial Perception of Services Delivered by Road } \\
\text { Department/Public Works (l=worst } 7=\text { best) }\end{array}$ & 5.3 & 4.1 & 3.7 & 5.5 & 3.9 & 4.4 & 4.0 & 3.6 & 3.4 & 4.1 & 4.3 & 4.0 \\
\hline $\begin{array}{l}\text { Commercial Perception of Port Facilities } \\
\text { (1=worst } 7=\text { best) }\end{array}$ & 4.7 & 3.8 & 3.8 & 4.1 & 3.4 & 3.6 & 3.1 & 3.6 & 2.6 & 3.6 & 5.4 & 4.2 \\
\hline $\begin{array}{l}\text { Commercial Perception of Railroad Services } \\
\text { (1=worst } 7=\text { best) }\end{array}$ & 4.3 & 2.9 & 3.2 & 3.5 & 3.6 & 3.1 & 1.5 & 3.7 & 2.7 & 2.7 & 4.8 & 3.4 \\
\hline $\begin{array}{l}\text { Commercial Perception of Air Transport Services } \\
\text { (l=worst } 7=\text { best) }\end{array}$ & 5.6 & 4.5 & 4.5 & 4.9 & 4.2 & 4.4 & 4.2 & 3.9 & 3.6 & 4.4 & 5.7 & 4.8 \\
\hline $\begin{array}{l}\text { Paved Roads } \\
\text { ( } \% \text { of total roads) }\end{array}$ & 21 & 57 & 25 & 56 & 38 & 32 & 36 & 76 & 30 & 52 & 82 & 50 \\
\hline
\end{tabular}

Note: Data used is from the latest observation available between 1997 and 2003.

Source: Estache, Antonio and Ana Goicoechea (2005). "A 'Research' Datahase on Infrastructure Economic Performance," Policy Research Paper No.3643, Infrastructure Network, 0ffice of the Vice President, Jure 2005.

\footnotetext{
${ }^{10}$ Department of Transport (1999) estimated that based on OHS data for 1995, the average public transport trip in South Africa was $20 \mathrm{~km}$, about twice the length experienced in Asian developing countries. South African commuters spent about $40 \%$ more time traveling than their Asian counterparts.
} 
Figure 7: Road Density in Terms of Population

20

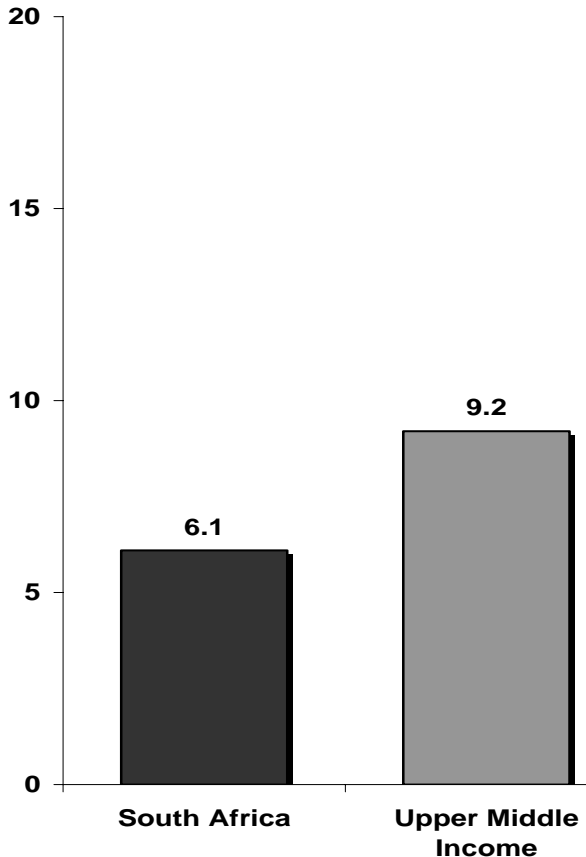
Income

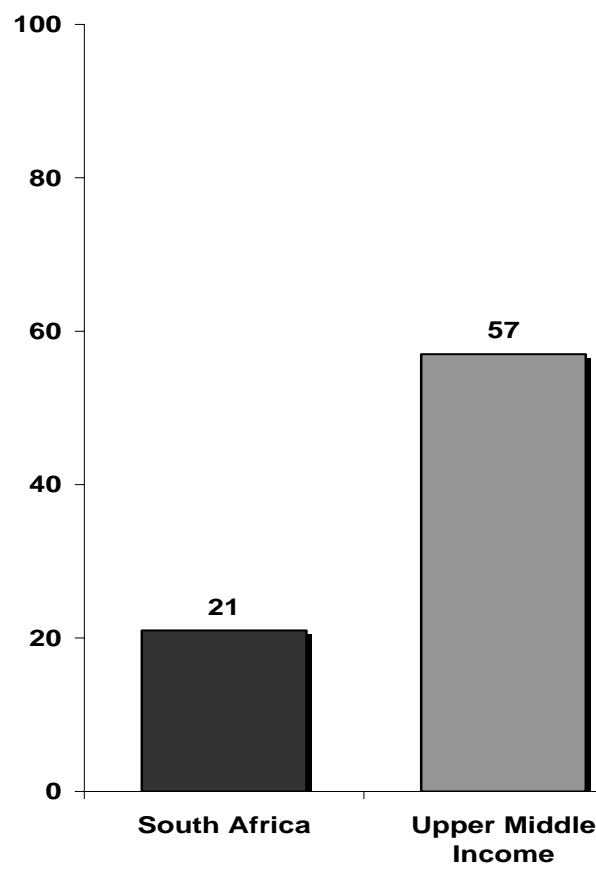

(road-km/1000 people)

17.3

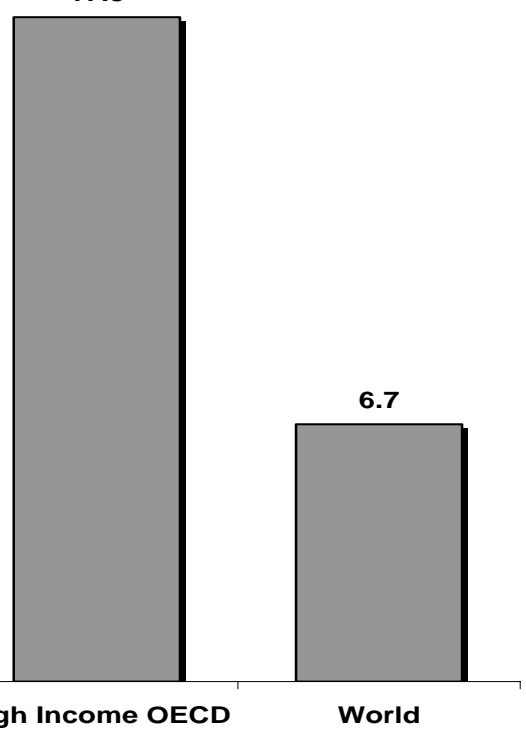

Figure 8: Paved Roads

(\% of total roads)
50

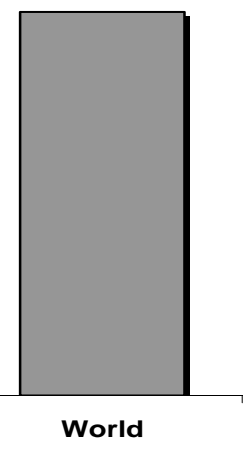




\section{Large differences from the benchmark}

As a conclusion to the detailed benchmarking of South Africa's infrastructure performance discussed above, it might be useful to highlight some of the large differences — positive and negative - against the areas where performance differences are small between South Africa and comparator groups of countries, especially the benchmark upper middle-income group. With appropriate caveats, this selection of indicators showing particularly "large deviations" (which we define as plus or minus 10\% from the benchmark) from the benchmark can be taken as indicative of the possible significant strengths and weaknesses in infrastructure performance. We also note the areas where performance has been broadly on par (within the $+/ 10 \%$ deviation from the benchmark) with that in upper middle income countries. Together with the additional, country specific indicators and analysis of sectors, it is hoped that this could help focus the attention of policymakers on those areas where performance improvements are most needed (Table 5).

In electricity, comparative indicators suggest that access remains a major issue, despite important gains in expanding access in recent years, while technical efficiency for the served population is relatively high. Indicators of internal technical efficiency (e.g., losses in distribution/transmission) and low prices are favorable compared with the benchmark country group as well as other comparators. These are comparatively strong dimensions of South Africa's performance in electricity. Also, the energy intensity, measured by the energy use per PPP GDP, appears broadly on par with that of the benchmark upper middle-income countries. However, indicators of access to network and reported access to service by households fall significantly short of what would be expected of a well-run sector in an upper middle-income country. While much was done in recent years to extend the service to the previously unserved population, much more remains to be done, especially in rural (and peri-urban) areas.

In water and sanitation, access is much lower than in benchmark upper-middle income countries, especially in rural areas. Quality indicators also indicate relative shortfalls. To the extent that the shortfalls reflect the internal imbalances between supply and demand for this vital service that is closely monitored internationally under the Millennium Development Goals (MDG) because of its multiple links with health and the general wellbeing, expanding access and quality in this sector may be particularly important.

In information and communications technology, pricing of services catering the wealthier segments of the population and the large, internationally oriented enterprise sector-cellular calls and some international calls (to the U.S., for example) - reflect generally good and competitively provided services. We note, however, that in the current debate, broadband speed and access in particular remain a strong area of concern. Arguably, broadband services are of particular concern to economic activity. ${ }^{11}$ Further, local service rates, which may be used relatively heavily by the middle class and the poorer segments of the population, are among the highest in the world. Finally, access rates, especially in poor, rural areas are much lower compared with the benchmark. The implication is that more could be done to raise competitiveness in the local service segment and generally expand access to the rural areas.

Finally, in transport, both road and rail, all basic indicators of performance show worse performance than the benchmark upper middle-income countries, even when accounting for some uncertainty about specific indicators and the caveats of interpretation. While this in part may reflect the peculiar territorial distribution of economic activity, population, markets, and transportable goods, it also reflects the legacy of the Apartheid. While more in-depth comparison of a more detailed battery of road indicators

\footnotetext{
${ }^{11}$ See Truen and Hodge (2005) and Reynolds (2005).
} 
of quality and quantity of service would be needed to draw firm conclusions, the indicators presented do suggest the need for a deeper look at the adequacy of the road and rail network to service the needs of a growing, upper middle income country, including large segments of the rural population.

Table 5: South Africa's Infrastructure Performance - Significant Deviation from Benchmark

\begin{tabular}{|c|c|c|c|c|c|}
\hline & $\begin{array}{l}\text { South } \\
\text { Africa }\end{array}$ & $\begin{array}{c}\text { Benchmark } \\
\text { Upper } \\
\text { Middle } \\
\text { Income } \\
\end{array}$ & SSA & World & \begin{tabular}{|c} 
South Africa's \\
performance vs. \\
Benchmark \\
\end{tabular} \\
\hline \multicolumn{6}{|l|}{ Deviation of $+10 \%$ or more from Benchmark } \\
\hline $\begin{array}{l}\text { Electricity: Average End-User Prices (US cents/kWh) - } \\
\text { (Residential/Non-Energy: Residential) }\end{array}$ & $3 / 2$ & $9 / 7$ & $6 / 5$ & $9 / 6$ & Outperform \\
\hline $\begin{array}{l}\text { Energy: Electric Power Transmission and Distribution Losses } \\
(\% \text { of total output) }\end{array}$ & 8.0 & 14.0 & 19.0 & 14.0 & Outperform \\
\hline $\begin{array}{l}\text { ICT: Cost of Phone Call to the US } \\
\text { (US cents } / 3 \text { minutes) }\end{array}$ & 58 & 305 & 497 & 335 & Outperform \\
\hline $\begin{array}{l}\text { ICT: Cost of Cellular Local Call } \\
\text { (US cents } / 3 \text { off-peak minutes) }\end{array}$ & 25 & 54 & 42 & 49 & Outperform \\
\hline \multicolumn{6}{|l|}{ Deviation of between $-10 \%$ and $+10 \%$ from Benchmark } \\
\hline $\begin{array}{l}\text { Enerty: Energy Use Per PPP GDP } \\
\text { (kg of oil equivalent/1000 PPP dollars, Constant 2000) }\end{array}$ & 257 & 249 & 364 & 275 & Average \\
\hline $\begin{array}{l}\text { Water: Access to Improved Water Sources } \\
(\% \text { of population) }\end{array}$ & 87 & 93 & 64 & 80 & Average \\
\hline $\begin{array}{l}\text { Water: Households Using Piped or Well Water as Main Source of } \\
\text { Drinking Water } \quad(\% \text { of households })\end{array}$ & 85 & 80 & 78 & 79 & Average \\
\hline $\begin{array}{l}\text { ICT: Cellular Teledensity } \\
\text { (cellular subscribers/1000 people) }\end{array}$ & 364 & 381 & 73 & 296 & Average \\
\hline \multicolumn{6}{|l|}{ Deviation of $-10 \%$ or more from Benchmark } \\
\hline $\begin{array}{l}\text { Energy: Access to Electricity Network } \\
(\% \text { of Population) }\end{array}$ & 66 & 87 & 15 & 60 & Underperform \\
\hline $\begin{array}{l}\text { Energy: Households Reporting Access to Electricity } \\
\text { (\% of households) }\end{array}$ & 65 & 74 & 23 & 45 & Underperform \\
\hline $\begin{array}{l}\text { Water: Access to Improved Sanitation } \\
\text { (\% of population) }\end{array}$ & 67 & 86 & 37 & 64 & Underperform \\
\hline $\begin{array}{l}\text { ICT: Mainlines Teledensity } \\
\text { (mainlines subscribers/1000 people) }\end{array}$ & 107 & 261 & 31 & 213 & Underperform \\
\hline $\begin{array}{l}\text { ICT: Cost of Local Phone Call } \\
\text { (US cents } / 3 \text { minutes) }\end{array}$ & 15 & 9 & 10 & 9 & Underperform \\
\hline $\begin{array}{l}\text { ICT: Phone Faults } \\
\text { (reported faults/100 mainlines) }\end{array}$ & 48 & 18 & 57 & 37 & Underperform \\
\hline $\begin{array}{l}\text { Transport: Road Density in Terms of Population } \\
\text { (road-km/1000 people) }\end{array}$ & 6.1 & 9.2 & 3.3 & 6.7 & Underperform \\
\hline $\begin{array}{l}\text { Transport: Road Density in Terms of Land } \\
\text { (road-km/1000 sq km) }\end{array}$ & 227 & 1076 & 156 & 841 & Underperform \\
\hline $\begin{array}{l}\text { Transport: Rail Lines Density in Terms of Land } \\
\text { (rail-km/1000 sq km) }\end{array}$ & 17 & 31 & 4 & 23 & Underperform \\
\hline $\begin{array}{l}\text { Transport: Travel Time to Work in Main Cities } \\
\text { (minutes/one-way work trip) }\end{array}$ & 35 & 29 & 34 & 31 & Underperform \\
\hline $\begin{array}{l}\text { Transport: Paved Roads } \\
\text { (\% of total roads) }\end{array}$ & 21 & 57 & 25 & 50 & Underperform \\
\hline
\end{tabular}

Note: Data used is from the latest observation available between 1997 and 2003.

Source: Estache, Antonio and Ana Goicoechea (2005). “A 'Research' Database on Infrastructure Economic Performance," Policy Research Paper No. 3643, Infrastructure Network, Office of the Vice President, June 2005. 


\section{The rural-urban divide}

Finally, given the clear "urban bias" of infrastructure distribution in many developing countries, including South Africa, no discussion of South Africa's infrastructure performance can be complete without at least a preliminary look at the rural-urban divide. However, internationally comparative data on urban and rural dimensions or infrastructure performance are limited. In the data base used, for example, there are no rural and urban data for transport directly available, and indicators for other sectors are generally more limited. Nevertheless, some available indicators do provide a glimpse of the important differences in infrastructure performance between rural and urban areas of South Africa (Table 6).

Table 6: Benchmarking Infrastructure Performance in Rural and Urban Areas in South Africa

\begin{tabular}{|c|c|c|c|c|c|c|}
\hline & \multicolumn{2}{|c|}{ South Africa } & \multicolumn{2}{|c|}{$\begin{array}{c}\text { Upper Middle } \\
\text { Income }\end{array}$} & \multicolumn{2}{|c|}{ SSA } \\
\hline & Rural & Urban & Rural & Urban & Rural & Urban \\
\hline $\begin{array}{l}\text { Households Reporting Access to Electricity } \\
(\% \text { of households) }\end{array}$ & 37 & 84 & 30 & 90 & 8 & 54 \\
\hline $\begin{array}{l}\text { Access to Improved Water Sources } \\
(\% \text { of population) }\end{array}$ & 73 & 98 & 85 & 96 & 54 & 83 \\
\hline $\begin{array}{l}\text { Access to Improved Sanitation } \\
(\% \text { of population) }\end{array}$ & 44 & 86 & 76 & 91 & 28 & 54 \\
\hline $\begin{array}{l}\text { Households with Own Telephone } \\
(\% \text { of households) }\end{array}$ & 6 & 43 & 1 & 17 & 1 & 10 \\
\hline
\end{tabular}

Mote: Data used is from the latest observation available between 1997 and 2003.

Source: Estache, Antonio and Ana Goicoechea (2005). “A 'Research' Database on Infrastructure Economic Performance," Policy Research Paper No. 3643, Infrastructure Network, Office of the Vice President, June 2005.

In a nutshell, the available indicators on electricity, water and sanitation, and telephone services suggest that while urban areas score relatively well, there is a significant shortfall in access to improved water and sanitation in rural areas of South Africa compared with the benchmark upper middle income countries. Therefore, territorial equity between rural and urban areas for some infrastructure services that may matter most for the poor - water and sanitation - is a major issue. In electricity, access in urban areas is lower than in upper middle-income countries, while in rural areas access is above the benchmark. This reflects major efforts (and gains) in recent years to expand access in South Africa; nevertheless, the overall access, as noted in the earlier sections of the paper, remains below the benchmark. In access to improved water and sanitation, however, rural areas of South Africa lag significantly behind their upper middle-income country counterparts. Finally, telephone ownership is South Africa appears to be better in both rural and rural areas than in the upper middle-income countries. This should not be taken automatically to imply better service, for which comparative indicators in rural areas are not available. In fact, as noted in the earlier sections, other aggregate indicators of telecom service performance (especially in local services) suggest considerable scope for improvement.

\section{Conclusion}

In sum, we have benchmarked South Africa's infrastructure performance on all four major infrastructure sectors in terms of key indicators of access, affordability-pricing, and quality using the new World Bank database of infrastructure sector outcome indicators from 207 countries. The broad results suggest the following: access remains a major issue in electricity and, especially, water and sanitation (particularly in rural areas), and so does performance in local telecom services. Even transport performance appears 
comparatively less strong than would be expected, though more in-depth analysis of comparative performance of transport may be warranted to develop a more nuanced picture, especially across different modes of transport. The main policy implication is that there remain significant needs to scale up infrastructure investments - especially in the yet unserved areas - and improve efficiency in all four major infrastructure sectors if South Africa's infrastructure performance is to catch up with its group of upper middle-income countries. In a separate paper, we provide panel-data based estimates of South Africa's investment needs in electricity and telecommunications sectors (Bogetić and Fedderke 2006).

More specifically, compared to the benchmark and other country groupings, South Africa's utilities provide solid service at reasonable quality and, in some cases, very competitive prices. But there remain significant shortfalls relative to benchmarks in all infrastructure sectors, largely related to limited access and less than expected quality, especially in rural areas, where large numbers of South Africa's poor live with limited or no access to service. To catch up with its income group in terms of these indicators, South Africa will need to improve access to and quality of electricity, and water and sanitation services in presently unserved areas. Indicators of transport performance, while less definitive, potentially also point in the same direction. Even in telecom, the most globalized and "modern" infrastructure sector, access in rural areas can be improved and pricing of local services remains uncompetitive. Moreover, to put it simply, if South Africa is to strengthen its overall infrastructure performance, it will need to improve these dimensions' performance in the sectors faster than the average country in the upper middle-income group while maintaining or improving its position in the already strong areas of performance. This will not be easy in competition within a group of countries all aspiring to move to much higher levels of income and with ambitious poverty reduction targets. But catching up with these relative shortfalls may also help South Africa reduce its economic inequities and poverty rates and, therefore, meet the infrastructure related Millennium Development Goals (MDGs). It could also help address some of the concerns about South Africa's external and industrial competitiveness and service delivery that in good part depends on the efficiency and capacity of network utilities to deliver basic services to population and businesses alike.

\section{References}

Aschauer, David.A. (1989). "Is public expenditure productive?" Journal of Monetary Economics, 23:177-200.

Bogetić, Željko and Johannes W. Fedderke (2006). "Forecasting Investment Needs in South Africa's Electricity and Telecommunications Sectors," World Bank Policy Research Paper Series (January), forthcoming.

Bogetić, Željko and Johannes W. Fedderke (2005). "Infrastructure and Growth in South Africa: Benchmarking, Productivity and Investment Needs," paper presented at the bi-annual conference of the Economic Society of South Africa (ESSA), Durban, September 7-9, 2005.

Easterly, W. and Servén, L. (2002). The Limits of Stabilization: Infrastructure, Public Deficits and Growth in Latin America, Stanford University Press and the World Bank.

Esfahni, H.S., and Ramirez, M.T., 2003, Institutions, infrastructure and economic growth, Journal of Development Economics, 70, 443-477. 
Estache, Antonio and Ana Goicoechea (2005). "A 'Research' Database on Infrastructure Economic Performance," Policy Research Paper No. 3643, The World Bank, Infrastructure Network, Office of the Vice President (June), Washington, D.C.

Fedderke, Johannes, W., Perkins P., and Luiz, J.M. (2005). "Infrastructural Investment in Long-Run Growth: South Africa 1875-2001," World Development, forthcoming.

Leipziger, Danny (2001). “The Unfinished Agenda: Why is Latin America Lagging Behind?" Finance \& Development, International Monetary Fund, vol. 38, 38-41.

Manuel, Trevor (2005). Budget Speech 2005, Ministry of Finance, Pretoria, South Africa, February 23.

Perkins, P., J.W. Fedderke, and J. M. Luiz (2005). “An Analysis of Economic Infrastructure Investment in South Africa," South African Journal of Economics, Vol. 73 (2), 211-28.

Reynolds, T, (2005). "Global developments in Telecommunications Pricing," OECD Presentation 14-15 July, Midrand, South Africa.

Truen, S., and Hodge, J. (2005). "Competitive conditions in international bandwidth markets in South Africa: Pricing and regulatory issues in the SAT-3 cable and satellite market," Mimeo: GenesisAnalytics.

World Bank (1994). World Development Report 1994: Infrastructure for Development. New York: Oxford University Press. 